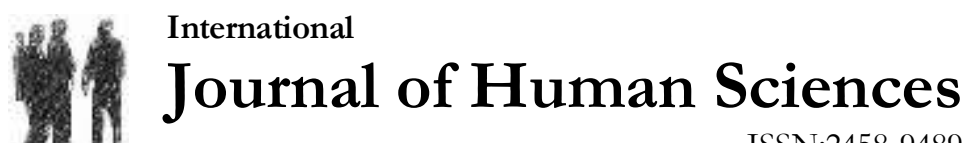 \\ ISSN:2458-9489
}

Volume 14 Issue 3 Year: 2017

\section{Examining to see elite sight-disabled athletes according to the dimensions of the scale of motivation in sport}

\author{
Hasan Erdem Mumcu ${ }^{1}$ \\ Mehmet Acet ${ }^{2}$ \\ Osman Kusan ${ }^{3}$ \\ Ömer Zambak ${ }^{4}$ \\ Mustafa Can Koç
}

\begin{abstract}
Made the purpose of this study is to examine to see disabled athletes according to the dimensions of the scale of motivation in sport. The study group is comprised of 168 visually impaired athletes in total, including 51 females and 117 males, identified by the targeted sampling method, between the ages of 15-25, who do sports at elite level. The Sport Motivation Scale (SMS) was developed by Pelletier (1995) basing on the Theory of Self Determination by Deci and Ryan (1985). The purpose of SMS is to determine the level of "internal motivation, external motivation and nonmotivation" of the person in the sports environment and to identify the source of motivation of the person (Kazak, 2004). Validity and reliability of the scale for Turkish athletes was studied by Kazak (2004). In conclusion, this study has demonstrated that to know and succeed and to experience stimuli and identification subdimensions are effective in sports attendance of visually impaired athletes engaged in sports at elite level. Moreover, it has been demonstrated that age, education level and sports branch variables have an impact on tendency for sports. It can be concluded that compared to older athletes, younger athletes have low tendency for sports because of anxiety and embarrassment and are not conscious about why they do sports. It has been concluded that athletes of weight lifting and judo, which have contribution to physical development at the top level, believe the nature of their sports branch contributes more to their physical development and their strength is acknowledged and appreciated by other people.
\end{abstract}

Keywords: Disability, Visually İmpairment Motivation, Sport Motivation, Sport Psycholog.

\section{INTRODUCTION}

For a disabled person actively engaged in sports, moral strength as well as increased physical strength increase their enjoyment and life quality. Paralympics or Disabled Olympics allowed people to understand that sport is a way of moral and physical recovery after an accident or a major disease (Ferrara and Peterson, 2000). Disabled people engaged in social activities will integrate with the society and move away from the feeling that they are excluded because of their disability (Seyyar, 2013). Seyyar (2013) highlighted the importance of creating a suitable environment for the disabled to act independently in their own social environment because of

\footnotetext{
${ }^{1}$ Lecturer,Hitit Universty,Phd student,Dumlupinar University erdemumcu@gmail.com

2 Associate Professor,Dumlupinar University, acetmehmet44@gmail.com

3 Phd Student,Dumlupinar University, osmankusan@hotmail.com

${ }^{4}$ Phd Student,Dumlupinar University, omer zambak@yahoo.com

${ }^{5}$ Lecturer,Istanbul Gelisim University, Phd student,Dumlupinar University, cankoc 01@,hotmail.com
} 
Mumcu, H. E., Acet, M., Kusan, O., Zambak, Ö., \& Koç, M. C. (2017). Examining to see elite sight-disabled athletes according to the dimensions of the scale of motivation in sport. Journal of Human Sciences, 14(3), 2590-2600. doi:10.14687/ihs.v14i3.4395

their physical and psycho-social characteristics and to establish healthy communication with people and providing socio-cultural and financial support.

We need a theory which is more solid (Crocker, 1993) and defines the structures which need to be clearly examined and the relations in between to study participation motivations in sports (Deci and Ryan, 1985, 1991) and an approach which meets this requirement is the Theory of Self Determination. This theory has subdimensions of internal motivation, external motivation and non-motivation. If individuals do sports for reasons such as knowing, succeeding, enjoying, spending time and experiencing stimuli, they are under the effect of internal motivation. If the person does sports because of factors such as family pressure or awards without self determination, then they are externally motivated (Deci and Ryan, 1985, 1991, 1996, 2002, Kazak 2004).

According to the Self Determination Theory, people have three main psychological needs. They are autonomy, competency and commitment (Deci and Ryan, 1985, Deci and Rayn, 2002). The Theory of Self Determination of Deci and Ryan suggests that people have a phsychologic well being level in proportion to satisfaction of these needs. The need for autonomy indicates the right to choose between the activities in the life of a person. It means a person determining his/her behaviors and deciding independently. This need is satisfied to the extent that the person has the right to choose. The second need is for competency and it is a "competency" state which is a result of people being able to use their own capacities. This need is believed to be satisfied in persons who are able to overcome their work with success and notice their competency after being appreciated for their work. The third and last need is for commitment and it indicates the sense of commitment to people in interaction. People have a need for commitment and their commitment will increase as persons feel belong to certain people or groups. Behaviors including being a member to a religion, being a fan or a political party sympathizer are a result of the motivation to meet this need (Deci and Ryan, 1985, Deci and Ryan, 2002). There are many studies supported by this theory, yet they have been mainly applied to athletes without a disability. Other studies compared disabled athletes to athletes without a disability (Perreault and Vallerand, 2007).

The idea that disabled athletes are trying to struggle with a vital trauma because of their condition, psychological emptiness because of a deprivation or a chronic disease and they have less psychological and motivational ability compared to nondisabled athletes is justifiable accurate. However, their motivation to cling to life with sports despite all deficiencies and deprivations is very important (Cox and David, 1992). Psychological needs of disabled people in sports have also priority in ensuring their motivation (Ruddel and Shinew, 2006). Irrespective of the type or severity of the disability, moving, exercising and participating in sports activities give joy to the person and the joy from moving is an important tool in meeting the needs of the person for entertainment and success as well as increasing vital motivation. Sport ensures physical, mental and social development of the disabled and contributes to their social integration (Eichsteadt and Lavay, 1995). Self determination is a continuous state. Nobody has total control over his/her entire life. Deaf and blind persons have the ability to control many areas but they may not be able to implement it in all areas like others. Changes in the level of this continuous ability and current assistance represent his/her personality. The personality and tendencies of the person affect all his/her needs as in the nature of self determination (Erwin and Brown, 2000).

It is hard to compare wheelchair athletes to nondisabled athletes but about a third of the athletes in this sports branch are nondisabled athletes in Canada (Brasile, 1992). As it is rare to see a sports environment where disabled and nondisabled athletes use their abilities on the same conditions, it is very important to have similarities in motivation and coping skills as this comparison is the first study in the history of sports based on the theory of self determination. The same results of this study among disabled athletes demonstrate it can be applied among disabled athletes and supports autonomous forms of the theory of self determination. This study 
Mumcu, H. E., Acet, M., Kusan, O., Zambak, Ö., \& Koç, M. C. (2017). Examining to see elite sight-disabled athletes according to the dimensions of the scale of motivation in sport. Journal of Human Sciences, 14(3), 2590-2600. doi:10.14687/ihs.v14i3.4395

can help us in understanding better the nature and results of motivation processes in disabled athletes (Perreault and Vallerand, 2007).

\section{METHODOLOGY}

The study group is comprised of 168 visually impaired athletes in total, including 51 females and 117 males, identified by the targeted sampling method, between the age of 15-25, who do sports at elite level.

\section{Data Collection Tools}

The Sport Motivation Scale (SMS) was developed by Pelletier et al. (1995) basing on the Theory of Self Determination by Deci and Ryan (1985). The purpose of SMS is to determine the level of "internal motivation, external motivation and nonmotivation" of the person in the sports environment and to identify the source of motivation of the person (Kazak, 2004). Validity and reliability of the scale for Turkish athletes was studied by Kazak (2004). The Sport Motivation Scale includes 28 items and 6 subscales where assessment is made at 7 levels. These subscales are: internal motivation for knowing, succeeding and experiencing stimuli, external arrangement, introjection, identification and nonmotivation.

\section{Data Analysis}

Data Collection and Analysis SMS was applied individually and in person by the researcher to 168 athletes. Data from the study was transferred to SPSS 17.0 software. Compliance of data with normal distribution was evaluated with Kolmogorov Smirnov test. Descriptive statistic analysis (average, standard deviation, frequency and percentage) was made for identification of characteristics of the study group in data analysis. The relationship between the scores of participants in SMS subscales in their age range (15-25 years old) and SMS subdimensions was evaluated with Pearson Product-Moment Correlation Analysis. The One Way Variance Analysis (ANOVA) was used to determine if SMS subdimensions differ with sports branch variables and the Bonferroni Post Hoc test analysis method was used when there was a difference (LSD and Scheffe). The t-test analysis method was used for independent groups to determine the differences in SMS subdimensions of athletes with the gender variable.

Table 1: Frequency Distribution By Demographic Characteristics of Visually Impaired Athletes in the Study

\begin{tabular}{|c|c|c|c|c|}
\hline VARIABLES & GROUPS & $\mathbf{N}$ & $\%$ & TOTAL \\
\hline \multirow[t]{2}{*}{ Gender } & Male & 117 & 69,6 & \multirow{2}{*}{168} \\
\hline & Female & 51 & 30,4 & \\
\hline \multirow{3}{*}{$\begin{array}{l}\text { Education } \\
\text { Level }\end{array}$} & Primary School & 25 & 14,9 & \multirow{3}{*}{168} \\
\hline & $\begin{array}{c}\text { Secondary - High } \\
\text { School }\end{array}$ & 114 & 67,9 & \\
\hline & University & 29 & 17,3 & \\
\hline \multirow{7}{*}{ Branch } & Judo & 25 & 14,9 & \multirow{7}{*}{168} \\
\hline & Futsal & 22 & 13,1 & \\
\hline & Athletics & 18 & 10,7 & \\
\hline & Goalball & 15 & 8,9 & \\
\hline & Swimming & 41 & 24,4 & \\
\hline & Chess & 19 & 11,3 & \\
\hline & Weight lifting & 28 & 16,7 & \\
\hline
\end{tabular}


Mumcu, H. E., Acet, M., Kusan, O., Zambak, Ö., \& Koç, M. C. (2017). Examining to see elite sight-disabled athletes according to the dimensions of the scale of motivation in sport. Journal of Human Sciences, 14(3), 2590-2600. doi:10.14687/ihs.v14i3.4395

168 visually impaired athletes, $69.6 \%$ of whom were male and $30.4 \%$ female, took part in the study. Of the visually impaired athletes, $14.9 \%$ received primary school, $67.9 \%$ secondaryhigh school and $17.3 \%$ university education. Considering the distribution of athletes, $14.9 \%$ are from judo, $13.1 \%$ futsal, $10.7 \%$ athletics, $8.9 \%$ goalball, $24.4 \%$ swimming, $11.3 \%$ chess and $16.7 \%$ weight lifting.

Table 2: T-Test for Differences by Gender in Average Scores of Motivation of Visually Impaired Athletes in the Study

\begin{tabular}{|c|c|c|c|c|c|c|c|c|}
\hline & Dimensions & Gender & $\mathbf{N}$ & $\overline{\boldsymbol{x}}$ & $\mathbf{S}$ & sd & $\mathbf{T}$ & $\mathrm{p}$ \\
\hline \multirow{6}{*}{ 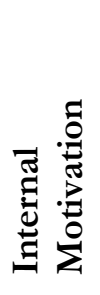 } & \multirow{2}{*}{$\begin{array}{l}\text { Internal Motivation } \\
\text { to Learn and Succeed }\end{array}$} & Male & 117 & 5,05 & 1,07 & \multirow[t]{2}{*}{166} & - & \multirow{2}{*}{, 190 } \\
\hline & & Female & 51 & 5,29 & 1,10 & & 1,317 & \\
\hline & \multirow{2}{*}{$\begin{array}{l}\text { Internal Motivation } \\
\text { to Experience Stimuli }\end{array}$} & Male & 117 & 5,28 & 1,17 & \multirow[t]{2}{*}{166} & \multirow{2}{*}{1,731} & \multirow{2}{*}{,085 } \\
\hline & & Female & 51 & 4,92 & 1,39 & & & \\
\hline & \multirow{2}{*}{$\begin{array}{l}\text { Subdimension } \\
\text { General }\end{array}$} & Male & 117 & 5,13 & ,93 & \multirow[t]{2}{*}{166} & \multirow{2}{*}{,- 250} & \multirow{2}{*}{,803 } \\
\hline & & Female & 51 & 5,17 & ,92 & & & \\
\hline \multirow{8}{*}{ 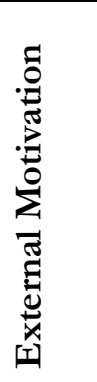 } & \multirow{2}{*}{$\begin{array}{l}\text { External } \\
\text { Arrangement }\end{array}$} & Male & 117 & 4,35 & 1,22 & \multirow[t]{2}{*}{166} & \multirow{2}{*}{,- 224} & \multirow{2}{*}{,823 } \\
\hline & & Female & 51 & 4,40 & 1,13 & & & \\
\hline & \multirow{2}{*}{ Identification } & Male & 117 & 4,90 & 1,07 & \multirow[t]{2}{*}{166} & \multirow{2}{*}{1,059} & \multirow{2}{*}{,291 } \\
\hline & & Female & 51 & 4,71 & 1,07 & & & \\
\hline & \multirow{2}{*}{ Introjection } & Male & 117 & 5,20 & 1,17 & \multirow[t]{2}{*}{166} & \multirow{2}{*}{,- 514} & \multirow{2}{*}{,608 } \\
\hline & & Female & 51 & 5,30 & 1,09 & & & \\
\hline & \multirow{2}{*}{$\begin{array}{l}\text { Subdimension } \\
\text { General }\end{array}$} & Male & 117 & 4,82 & 84 & \multirow[t]{2}{*}{166} & \multirow{2}{*}{,109 } & \multirow{2}{*}{ 914 } \\
\hline & & Female & 51 & 4,80 & 84 & & & \\
\hline & \multirow{2}{*}{ Nonmotivation } & Male & 117 & 2,13 & 86 & \multirow[t]{2}{*}{166} & \multirow{2}{*}{1,792} & \multirow{2}{*}{,075 } \\
\hline & & Female & 51 & 1,88 & ,68 & & & \\
\hline
\end{tabular}

According to Table 2, there is no statistically significant difference by the gender variable in internal motivation and subscale average scores.

$[\mathrm{t} 1(166)=-1.317 \mathrm{p}=.190>.05, \mathrm{t} 2(166)=1.731 \mathrm{p}=.085>.05, \mathrm{t} 3(166)=-.250 \mathrm{p}=.803>.05]$.

Table 3: Correlation Test for the Relationship Between Ages and Internal Motivation of Visually Impaired Athletes in the Study

\begin{tabular}{|l|c|c|c|}
\hline & \multicolumn{3}{|c|}{ Age - Internal Motivation } \\
\hline & $\begin{array}{c}\text { Internal Motivation to } \\
\text { Know and Succeed }\end{array}$ & $\begin{array}{c}\text { Internal Motivation to } \\
\text { Experience Stimuli }\end{array}$ & $\begin{array}{c}\text { Subdimensio } \\
\text { n General }\end{array}$ \\
\hline $\begin{array}{l}\text { Pearson } \\
\text { Correlation }\end{array}$ &,- 235 &, 225 &,- 082 \\
\hline Sig. (2-tailed) &, $002^{* *}$ &, $003^{* * *}$ &, 290 \\
\hline $\mathrm{N}$ & 168 & 168 & 168 \\
\hline
\end{tabular}

According to Table 3, there is a statistically significant, negative and low relationship between the subscale of internal motivation to know and succeed and ages of disabled athletes. [ $\mathrm{r}=-.235 \mathrm{p}=.002<.05]$.

There is a statistically significant, positive, low and linear relationship between the subscale of motivation to experience stimuli and ages of the visually impaired athletes in the study.[r $=.225 \mathrm{p}=.003<.05]$

There is no statistically significant relationship between the ages and the general of internal motivation subdimension of the disabled athletes in the study. [r= $-.082 \mathrm{p}=.290>.05]$ 
Mumcu, H. E., Acet, M., Kusan, O., Zambak, Ö., \& Koç, M. C. (2017). Examining to see elite sight-disabled athletes according to the dimensions of the scale of motivation in sport. Journal of Human Sciences, 14(3), 2590-2600. doi:10.14687/ihs.v14i3.4395

Table 4: Correlation Test for the Relationship Between Ages and External Motivation of Visually Impaired Athletes in the Study

\begin{tabular}{|l|c|c|c|c|}
\hline & \multicolumn{4}{|c|}{ Age - External Motivation } \\
\hline & $\begin{array}{c}\text { External } \\
\text { Arrangement }\end{array}$ & Identification & Introjection & $\begin{array}{c}\text { Subdimensio } \\
\text { n General }\end{array}$ \\
\hline $\begin{array}{l}\text { Pearson } \\
\text { Correlation }\end{array}$ &,- 093 &,- 262 &, 108 &,- 106 \\
\hline Sig. (2-tailed) &, 232 &, $001^{*}$ &, 163 &, 173 \\
\hline N & 168 & 168 & 168 & 168 \\
\hline
\end{tabular}

According to Table 4, there is no statistically significant relationship between external arrangement, the subscale of introjection and external motivation and ages of the visually impaired athletes.

$$
[\mathrm{r} 1=-.093 \mathrm{p}=.232>.05, \mathrm{r} 3=.108 \mathrm{p}=.163>.05, \mathrm{r} 4=-.106 \mathrm{p}=.173>.05]
$$

There is a statistically significant, negative, low and linear relationship between the subscale of identification and ages of the visually impaired athletes in the study.

$$
[\mathrm{r} 2=-.262 \mathrm{p}=.001<.05]
$$

Table 5: Correlation Test for the Relationship Between Ages and Nonmotivation of Visually Impaired Athletes in the Study

\begin{tabular}{|l|c|}
\hline & Nonmotivation \\
\hline $\begin{array}{l}\text { Pearson } \\
\text { Correlation }\end{array}$ &, 134 \\
\hline Sig. (2-tailed) &, 084 \\
\hline $\mathrm{N}$ & 168 \\
\hline
\end{tabular}

There is no statistically significant relationship between the ages and the subdimension of non-motivation of the disabled athletes in the study. $[\mathrm{r}=.134 \mathrm{p}=.084>.05]$

Table 6: ANOVA Test for Differences by Education Level in Average Scores of

\begin{tabular}{|c|c|c|c|c|c|c|c|}
\hline & Dimensions & $\begin{array}{l}\text { Education } \\
\text { Level }\end{array}$ & $\mathbf{N}$ & $\overline{\boldsymbol{x}}$ & S & F & $\mathbf{P}$ \\
\hline \multirow{9}{*}{ 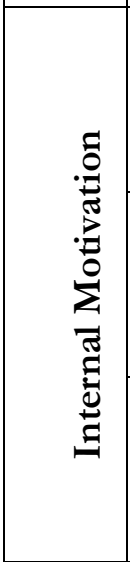 } & \multirow{3}{*}{$\begin{array}{l}\text { Internal Motivation } \\
\text { to Know and Succeed }\end{array}$} & Primary & 25 & 5,66 &, 83 & \multirow{3}{*}{5,496} & \multirow{3}{*}{, 005} \\
\hline & & $\begin{array}{l}\text { Secondary-High } \\
\text { School }\end{array}$ & 114 & 5,11 & 1,11 & & \\
\hline & & University & 29 & 4,70 & ,98 & & \\
\hline & \multirow{3}{*}{$\begin{array}{l}\text { Internal Motivation } \\
\text { to Experience Stimuli }\end{array}$} & Primary & 25 & 4,43 & 1,65 & \multirow{3}{*}{5,952} & \multirow{3}{*}{,003 } \\
\hline & & $\begin{array}{c}\text { Secondary-High } \\
\text { School }\end{array}$ & 114 & 5,35 & 1,07 & & \\
\hline & & University & 29 & 5,10 & 1,32 & & \\
\hline & \multirow{3}{*}{$\begin{array}{l}\text { Subdimension } \\
\text { General }\end{array}$} & Primary & 25 & 5,25 & 85 & \multirow{3}{*}{1,951} & \multirow{3}{*}{,145 } \\
\hline & & $\begin{array}{l}\text { Secondary-High } \\
\text { School }\end{array}$ & 114 & 5,19 & ,94 & & \\
\hline & & University & 29 & 4,83 & 90 & & \\
\hline \multirow{3}{*}{ 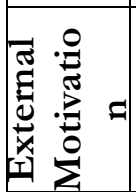 } & \multirow{3}{*}{$\begin{array}{l}\text { External } \\
\text { Arrangement }\end{array}$} & Primary & 25 & 3,90 & 1,19 & \multirow{3}{*}{4,495} & \multirow{3}{*}{,013 } \\
\hline & & $\begin{array}{l}\text { Secondary-High } \\
\text { School }\end{array}$ & 114 & 4,55 & 1,15 & & \\
\hline & & University & 29 & 4,05 & 1,23 & & \\
\hline
\end{tabular}
Motivation of Visually Impaired Athletes in the Study 
Mumcu, H. E., Acet, M., Kusan, O., Zambak, Ö., \& Koç, M. C. (2017). Examining to see elite sight-disabled athletes according to the dimensions of the scale of motivation in sport. Journal of Human Sciences, 14(3), 2590-2600. doi:10.14687/ihs.v14i3.4395

\begin{tabular}{|c|c|c|c|c|c|c|}
\hline \multirow{3}{*}{ Identification } & Primary & 25 & 5,35 & 1,04 & \multirow{3}{*}{5,918} & \multirow{3}{*}{,003 } \\
\hline & $\begin{array}{l}\text { Secondary-High } \\
\text { School }\end{array}$ & 114 & 4,85 & 1,06 & & \\
\hline & University & 29 & 4,37 & ,95 & & \\
\hline \multirow{3}{*}{ Introjection } & Primary & 25 & 5,13 & 1,03 & \multirow{3}{*}{, 169} & \multirow{3}{*}{,845 } \\
\hline & $\begin{array}{l}\text { Secondary-High } \\
\text { School }\end{array}$ & 114 & 5,27 & 1,18 & & \\
\hline & University & 29 & 5,20 & 1,14 & & \\
\hline \multirow{3}{*}{$\begin{array}{l}\text { Subdimension } \\
\text { General }\end{array}$} & Primary & 25 & 4,79 & ,76 & \multirow{3}{*}{2,015} & \multirow{3}{*}{,137 } \\
\hline & $\begin{array}{c}\text { Secondary-High } \\
\text { School }\end{array}$ & 114 & 4,89 & ,86 & & \\
\hline & University & 29 & 4,54 & ,79 & & \\
\hline \multirow{3}{*}{ Nonmotivation } & Primary & 25 & 2,33 & ,81 & \multirow{3}{*}{2,358} & \multirow{3}{*}{,098 } \\
\hline & $\begin{array}{l}\text { Secondary-High } \\
\text { School }\end{array}$ & 114 & 1,96 & ,79 & & \\
\hline & University & 29 & 2,17 & ,87 & & \\
\hline
\end{tabular}

According to Table 6, as p value calculated for internal motivation to know and succeed and internal motivation to experience stimuli subscales is lower than $\alpha=.05$ value accepted to be the significance level, there is a statistically significant difference by the education level variable in average scores of subscales of internal motivation to know and succeed and internal motivation to experience stimuli. There is no statistically significant difference by the education level variable in average score in the general of subdimension of internal motivation of the visually impaired athletes in the study.

$$
[\mathrm{F} 1(2-165)=5.496 \mathrm{p}=.005<.05, \mathrm{~F} 2(2-165)=5.952 \mathrm{p}=.003<.05, \quad \mathrm{~F} 3(2-165)=1.951
$$
$\mathrm{p}=.145>.05]$.

Considering the results of Tukey HSD dual comparison test applied for the difference between groups (LSD to understand the source of difference between groups), there is not any dual group which has a difference in average scores of the subscale of internal motivation to know and succeed. Dual groups which have a difference in average scores of the subscale of internal motivation to experience stimuli are university and primary school and are to the benefit of university.

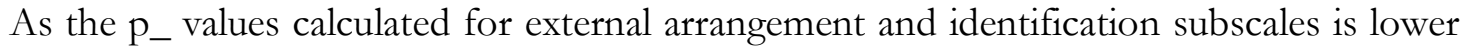
than $\alpha=.05$ value considered to be the significance level, there is a statistically significant difference by the education level variable in average scores of subscales of external arrangement and identification. As the $\mathrm{p}$ value calculated for external arrangement subdimension and introjection subscale is higher than $\alpha=.05$, there is no statistically significant difference by the average score of external arrangement subdimension and introjection subscale of the visually impaired athletes. $[\mathrm{F} 1(2-165)=4.495 \mathrm{p}=.013<.05, \mathrm{~F} 2(2-165)=5.918 \mathrm{p}=.003<.05, \mathrm{~F} 3(2-165)=.169$ $\mathrm{p}=.845>.05, \mathrm{~F} 4(2-165)=2.015 \mathrm{p}=.137>.05]$.

Considering the results of Tukey HSD dual comparison test applied for the difference between groups (LSD to understand the source of difference between groups), the dual group which has a difference in average scores of the external arrangement and the subscale of external motivation for identification is primary school and other two groups and to the benefit of the primary school.

According to Table 6 , as the $\mathrm{p}_{-}$value calculated for nonmotivation subdimension is higher than $\alpha=.05$ value considered to be the significance level, there is no statistically significant difference by the education level variable in nonmotivation of the visually impaired athletes. $[\mathrm{F}(2$ $165)=2.358 \mathrm{p}=.098>.05$ ] 
Mumcu, H. E., Acet, M., Kusan, O., Zambak, Ö., \& Koç, M. C. (2017). Examining to see elite sight-disabled athletes according to the dimensions of the scale of motivation in sport. Journal of Human Sciences, 14(3), 2590-2600. doi:10.14687/jhs.v14i3.4395

Table 7: ANOVA Test for Differences by Sports Branch in Average Scores of Internal Motivation Subdimension and Subscales of Visually Impaired Athletes in the Study

\begin{tabular}{|c|c|c|c|c|c|c|c|c|}
\hline & Dimensions & Sports Branch & $\mathbf{N}$ & $\bar{x}$ & $\mathbf{S}$ & $\mathbf{F}$ & $\mathrm{p}$ & $\begin{array}{c}\text { Differen } \\
\text { t } \\
\text { Groups }\end{array}$ \\
\hline \multirow{21}{*}{ 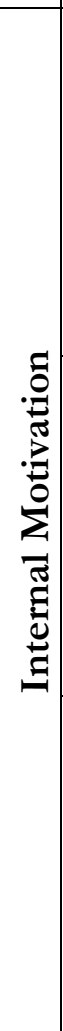 } & \multirow{7}{*}{$\begin{array}{l}\text { Internal Motivation } \\
\text { to Know and } \\
\text { Succeed }\end{array}$} & 1) Judo & 25 & 5,11 & 1,37 & \multirow{7}{*}{2,292} & \multirow{7}{*}{,038 } & \multirow{7}{*}{$2+1$} \\
\hline & & 2) Futsal & 22 & 5,01 &, 56 & & & \\
\hline & & 3) Athletics & 18 & 5,70 &, 95 & & & \\
\hline & & 4) Goalball & 15 & 5,59 &, 82 & & & \\
\hline & & 5) Swimming & 41 & 4,90 & 1,08 & & & \\
\hline & & 6) Chess & 19 & 5,35 & 1,20 & & & \\
\hline & & 7) Weight Lifting & 28 & 4,79 & 1,09 & & & \\
\hline & \multirow{7}{*}{$\begin{array}{l}\text { Internal Motivation } \\
\text { to Experience } \\
\text { Stimuli }\end{array}$} & 1) Judo & 25 & 5,54 & ,96 & \multirow{7}{*}{21,45} & \multirow{7}{*}{,000 } & \multirow{7}{*}{$\begin{array}{l}1-6 \\
2-6 \\
3-6 \\
4-6 \\
5-6 \\
6-7\end{array}$} \\
\hline & & 2) Futsal & 22 & 5,59 &, 71 & & & \\
\hline & & 3) Athletics & 18 & 5,40 & 1,00 & & & \\
\hline & & 4) Goalball & 15 & 6,03 & ,92 & & & \\
\hline & & 5) Swimming & 41 & 5,14 & 1,06 & & & \\
\hline & & 6) Chess & 19 & 2,93 &, 71 & & & \\
\hline & & 7) Weight Lifting & 28 & 5,47 & 1,05 & & & \\
\hline & \multirow{7}{*}{$\begin{array}{l}\text { Subdimension } \\
\text { General }\end{array}$} & 1) Judo & 25 & 5,25 & 1,14 & \multirow{7}{*}{3,752} & \multirow{7}{*}{,002 } & \multirow{7}{*}{$\begin{array}{l}3-6 \\
4-5 \\
4-6\end{array}$} \\
\hline & & 2) Futsal & 22 & 5,20 &, 48 & & & \\
\hline & & 3) Athletics & 18 & 5,60 &, 85 & & & \\
\hline & & 4) Goalball & 15 & 5,73 &, 78 & & & \\
\hline & & 5) Swimming & 41 & 4,98 & ,93 & & & \\
\hline & & 6) Chess & 19 & 4,54 &, 88 & & & \\
\hline & & 7) Weight Lifting & 28 & 5,02 &, 86 & & & \\
\hline
\end{tabular}

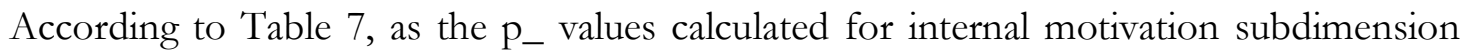
and subscales is lower than $\alpha=.05$ value considered to be the significance level, there is a statistically significant difference by the branch variable in average scores of internal motivation and subscales. [ F1 $(6-161)=2.292 \mathrm{p}=.038<.05, \mathrm{~F} 2(6-161)=21.450 \mathrm{p}=.000<.05, \mathrm{~F} 3(6-161)=$ $3.752 \mathrm{p}=.002<.05]$.

Considering the results of Tukey HSD dual comparison test applied for the difference between groups (Scheffe to understand the source of difference between groups), there is not any dual group which has a difference in average scores of the subscale of internal motivation to know and succeed. Dual groups which have a difference in average scores of the subscale of internal motivation to experience stimuli are chess and all of the other sports branches. It is to the benefit of the chess sports branch. Dual groups which have a difference in average scores in the general of the subdimension of internal motivation are athletics-chess and to the benefit of athletics. There are goalball-swimming and goalball-chess sports branches. It is to the benefit of the goalball sports branch. 
Mumcu, H. E., Acet, M., Kusan, O., Zambak, Ö., \& Koç, M. C. (2017). Examining to see elite sight-disabled athletes according to the dimensions of the scale of motivation in sport. Journal of Human Sciences, 14(3), 2590-2600. doi:10.14687/ihs.v14i3.4395

Table 8: ANOVA Test for Differences by Branch Variable in Average Scores of External Motivation Subdimension and Subscales of Visually Impaired Athletes in the Study

\begin{tabular}{|c|c|c|c|c|c|c|c|c|}
\hline & Dimensions & Sports Branch & $\mathbf{N}$ & $\overline{\boldsymbol{x}}$ & $\mathbf{S}$ & $\mathbf{F}$ & $\mathrm{p}$ & $\begin{array}{c}\text { Different } \\
\text { Groups }\end{array}$ \\
\hline \multirow{28}{*}{ 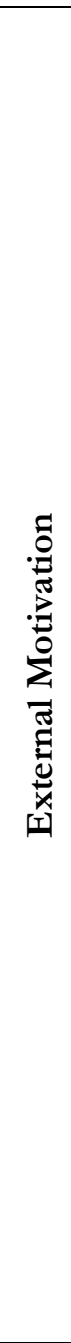 } & \multirow{7}{*}{$\begin{array}{l}\text { External } \\
\text { Arrangement }\end{array}$} & 1) Judo & 25 & 4,95 & 1,15 & \multirow{7}{*}{7,495} & \multirow{7}{*}{,000 } & \multirow{7}{*}{$\begin{array}{l}1-6 \\
1-7 \\
2-6 \\
2-7 \\
4-6 \\
4-7\end{array}$} \\
\hline & & 2) Futsal & 22 & 4,71 &, 89 & & & \\
\hline & & 3) Athletics & 18 & 4,55 & ,99 & & & \\
\hline & & 4) Goalball & 15 & 5,21 &, 85 & & & \\
\hline & & 5) Swimming & 41 & 4,35 & 1,01 & & & \\
\hline & & 6) Chess & 19 & 3,53 & ,89 & & & \\
\hline & & 7) Weight Lifting & 28 & 3,59 & 1,42 & & & \\
\hline & \multirow{7}{*}{ Identification } & 1) Judo & 25 & 5,18 & 1,00 & \multirow{7}{*}{4,439} & \multirow{7}{*}{,000 } & \multirow{7}{*}{$\begin{array}{l}1-7 \\
3-7 \\
4-7 \\
6-7\end{array}$} \\
\hline & & 2) Futsal & 22 & 4,82 &, 74 & & & \\
\hline & & 3) Athletics & 18 & 5,34 & 1,24 & & & \\
\hline & & 4) Goalball & 15 & 5,13 & ,66 & & & \\
\hline & & 5) Swimming & 41 & 4,64 & 1,06 & & & \\
\hline & & 6) Chess & 19 & 5,21 & 1,08 & & & \\
\hline & & 7) Weight Lifting & 28 & 4,12 & 1,05 & & & \\
\hline & \multirow{7}{*}{ Introjection } & 1) Judo & 25 & 5,23 & 1,58 & \multirow{7}{*}{1,499} & \multirow{7}{*}{,182 } & \multirow{7}{*}{ - } \\
\hline & & 2) Futsal & 22 & 5,36 & ,64 & & & \\
\hline & & 3) Athletics & 18 & 5,55 &, 87 & & & \\
\hline & & 4) Goalball & 15 & 5,33 & ,86 & & & \\
\hline & & 5) Swimming & 41 & 5,14 & 1,22 & & & \\
\hline & & 6) Chess & 19 & 4,60 & ,94 & & & \\
\hline & & 7) Weight Lifting & 28 & 5,46 & 1,23 & & & \\
\hline & \multirow{7}{*}{$\begin{array}{l}\text { Subdimension } \\
\text { General }\end{array}$} & 1) Judo & 25 & 5,12 & ,99 & \multirow{7}{*}{3,752} & \multirow{7}{*}{,002 } & \multirow{7}{*}{$\begin{array}{l}1-7 \\
3-7 \\
4-7\end{array}$} \\
\hline & & 2) Futsal & 22 & 4,96 &, 50 & & & \\
\hline & & 3) Athletics & 18 & 5,15 &, 72 & & & \\
\hline & & 4) Goalball & 15 & 5,22 & ,60 & & & \\
\hline & & 5) Swimming & 41 & 4,71 & ,83 & & & \\
\hline & & 6) Chess & 19 & 4,45 & ,65 & & & \\
\hline & & 7) Weight Lifting & 28 & 4,39 & ,97 & & & \\
\hline
\end{tabular}

According to Table 8, as the $\mathrm{p}_{-}$values calculated for external motivation subdimension and external arrangement, identification subscales is lower than $\alpha=.05$ value considered to be the significance level, there is a statistically significant difference by the sports branch variable in average scores of external motivation and subscales of visually impaired athletes. As the $p$ value calculated for introjection subscale is higher than $\alpha=.05$, there is no statistically significant difference by the average scores of introjection subscale of the visually impaired athletes.

$[\mathrm{F} 1(6-161)=7.495 \mathrm{p}=.000<.05, \quad \mathrm{~F} 2(6-161)=4.439 \mathrm{p}=.000<.05, \quad \mathrm{~F} 3(6-161)=1.499$ $\mathrm{p}=.182>.05$,

$\mathrm{F} 4(6-161)=3.752 \mathrm{p}=.002<.05]$.

Considering the results of Tukey HSD dual comparison test applied for the difference between groups (Scheffe to understand the source of difference between groups), dual groups which have a difference in external arrangement subscale average scores are judo-chess, judoweight lifting, futsal-chess, futsal-weight lifting, goalball-chess and goalball-weight lifting sports branch athletes. It is to the benefit of weight lifting and judo sport branches.

Dual groups which have a difference in average scores of identification subscale are judoweight lifting, athletics-weight lifting, goalball-weight lifting and chess-weight lifting and to the 
Mumcu, H. E., Acet, M., Kusan, O., Zambak, Ö., \& Koç, M. C. (2017). Examining to see elite sight-disabled athletes according to the dimensions of the scale of motivation in sport. Journal of Human Sciences, 14(3), 2590-2600. doi:10.14687/ihs.v14i3.4395

benefit of weight lifting. There is not any dual group which has a difference in introjection subscale average scores. Dual groups which have a difference in average scores in the general of the subdimension of external motivation are judo-weight lifting, athletics-weight lifting, goalballweight lifting and to the benefit of weight lifting.

Table 9: ANOVA Test for Differences by Branch in Average Scores of Nonmotivation of Visually Impaired Athletes in the Study

\begin{tabular}{|c|c|c|c|c|c|c|c|}
\hline Dimensions & $\begin{array}{l}\text { Sports } \\
\text { Branch }\end{array}$ & $\mathbf{N}$ & $\overline{\boldsymbol{x}}$ & $\mathbf{S}$ & $\mathbf{F}$ & $\mathrm{p}$ & $\begin{array}{c}\text { Different } \\
\text { Groups }\end{array}$ \\
\hline \multirow{7}{*}{ Nonmotivation } & 1) Judo & 25 & 2,11 &, 85 & \multirow{7}{*}{2,412} & \multirow{7}{*}{,029 } & \multirow{7}{*}{$4-7$} \\
\hline & 2) Futsal & 22 & 1,85 & ,79 & & & \\
\hline & 3) Athletics & 18 & 2,22 &, 86 & & & \\
\hline & 4) Goalball & 15 & 1,46 & 41 & & & \\
\hline & 5) Swimming & 41 & 2,03 & 67 & & & \\
\hline & 6) Chess & 19 & 2,18 & ,68 & & & \\
\hline & $\begin{array}{l}\text { 7) Weight } \\
\text { Lifting }\end{array}$ & 28 & 2,33 & 1,06 & & & \\
\hline
\end{tabular}

According to Table 9, as the $\mathrm{p}_{-}$value calculated for nonmotivation subdimension is higher than $\alpha=.05$ value considered to be the significance level, there is a statistically significant difference by the branch variable in nonmotivation of the visually impaired athletes.

$[\mathrm{F}(6-161)=2.412 \mathrm{p}=.029<.05]$

Considering the results of Tukey HSD dual comparison test applied for the difference between groups (Scheffe to understand the source of difference between groups), dual groups which have a difference in average scores of nonmotivation are goalball-futsal sports branch athletes and to the benefit of goalball.

\section{DISCUSSIONS AND CONCLUSION}

This study aims at examining the difference of motivational tendencies of visually impaired athletes in terms of gender, age, education level and sports branch competition category from the perspective of the Self Determination Theory. It can be concluded that all participants in the study attended in a sports branch by rather self determination basing on the high scores in subscales of "to experience stimuli and identification" among SMS subdimensions, moreover, university student athletes have higher scores in the subdimension "to know and succeed" compared to others. It is understood from the findings that the averages in the subdimensions of "external arrangement" are high. The lowest average is in the "nonmotivation" subdimension futsal and goalball sports branches. These results are generally predominant although they play a key role in understanding why persons attend the sports branch and internal and external reasons are effective at the same time for the same person. Internal motivation is reported to lead to higher levels of sportsmanship and motivation in those who start doing sports (Ryska, 2003; Wank and Biddle, 2004) and cause less burn out (Ryska, vd., 2002). However, many studies demonstrated that athletes participate in sports with both internal and external motivation (Bakker, 1993; Deci and Rayn, 1991, 2000, 2002). It was suggested that external motives were important for participation in sports but internal motives were more important to continue doing sports. Moreover, the reasons for not attending sports activities can include various reasons including looking for excitement, acquiring new skills and coping with challenges. In this regard, athletes get motivated to attend the sports environment for certain reasons such as having fun and improving their performance (Deci and Ryan, 1985, 1991). 
Mumcu, H. E., Acet, M., Kusan, O., Zambak, Ö., \& Koç, M. C. (2017). Examining to see elite sight-disabled athletes according to the dimensions of the scale of motivation in sport. Journal of Human Sciences, 14(3), 2590-2600. doi:10.14687/ihs.v14i3.4395

With increased age, "internal motivation" to know and succeed levels decrease and internal motivation "to experience stimuli" increase in visually impaired athletes. With lower average ages, there is higher internal motivation in sports attendance for enjoying better physical condition and improved physical performance. These findings support the results generally reported by the self determination theory. Accordingly, for example, basketball players who play to learn new offense techniques have this kind of motivation. Considering motivation to succeed, a person engages in an activity because of enjoying succeeding or creating a new thing. A football player who works on improving on a shooting technique is an example for this kind of motivation (Fortier, Vallerand and Guay, 1995). This indicates children and young athletes rather attend sports activities for internal reasons. It is normal to have different results for different groups. It is also normal for new athletes to express their efforts to reveal their capacity as the reason to continue with the sports environment. As a result of increasing age, increasing experience in the sports environment and this condition preventing their ambition to learn new things and have new experiences, their internal motivation levels can fall down and can be replaced by other feelings.

According to the education level variable of visually impaired athletes, in university student or graduate athletes, internal motivation average scores were higher compared to the subdimension of experiencing stimuli. It can be concluded that university student and graduate athletes have their motivations to enjoy and experience stimuli in sports at the forefront. The important factor in sports motivation is not an award but the importance of the activity itself. It is for having joy and using time efficiently through activities (Deci ve Rayn, 2000).

Considering internal motivation of visually impaired athletes by the sports branch variable, the athletes in the chess sports branch are motivated more according to to the subdimension of experiencing stimuli of internal motivation compared to other athletes. It is stated that athletes engaged in chess feel themselves better when they learn a new thing and their motivation is higher when they improve their skills.

Considering external motivations scores by the sports branch variable of visually impaired athletes, weight lifting and judo athletes are more motivated in external arrangement and identification subdimensions compared to other athletes. It can be suggested that the reason is weight lifting and judo athletes believe the nature of their sports branch contributes more to their physical development and their strength is acknowledged and appreciated by other people.

Considering nonmotivation scores by the sports branch variable of visually impaired athletes, nonmotivation scores are high for the athletes in goalball and futsal sports branches. Between the groups, average scores of goallball athletes are higher. The conclusion is that visually impaired team sport athletes are less motivated in the sports environment and have less reasons for participation compared to individual sports athletes. The fact that individual athletes like the psychological challenges in the sports environment, developing their skills, having expertise in the branch, being satisfied with their success, the feeling of being appreciated, medals and awards and other external and internal reasons can be an indicator of predominance compared to team sports athletes.

Attendance in sports and continuing with a sports branch can be a result of willing to learn new things, ambition for success, enjoyment, desire to become a member to a group and other internal reasons as well as external reasons such as awards, appreciation and status (Moral, Doğan, Kazak and Engür, 2004). Our study has certain data to support these results.

In conclusion, this study has demonstrated that to know and succeed and to experience stimuli and identification subdimensions are effective in sports attendance of visually impaired athletes engaged in sports at elite level. Moreover, it has been demonstrated that age, education level and sports branch variables have an impact on tendency for sports. It can be concluded that compared to older athletes, younger athletes have low tendency for sports because of anxiety and embarrassment and are not conscious about why they do sports. It has been concluded that 
Mumcu, H. E., Acet, M., Kusan, O., Zambak, Ö., \& Koç, M. C. (2017). Examining to see elite sight-disabled athletes according to the dimensions of the scale of motivation in sport. Journal of Human Sciences, 14(3), 2590-2600. doi:10.14687/ihs.v14i3.4395

athletes of weight lifting and judo, which have contribution to physical development at the top level, believe the nature of their sports branch contributes more to their physical development and their strength is acknowledged and appreciated by other people.

\section{REFERENCES}

Bakker, F. C., De Koning, J. J., Van Ingen Schenau, G. J., and De Groot, G. (1993). Motivation of young elite speed skaters, International Journal of Sport Psychology, 24, 432-442.

Brasile, F. M. (1992). A developmental perspective. A rejoinder to "Examining the concept of reverse integration." Adapted Physical Activity Quartely, 9, 293-304.

Cox, R. and Davis, R. (1992). Psychological skills of elite wheelchair athletes. Palaestra, 8(3), 16-28.

Crocker, P. R .E. (1993). Sport and exercise psychology and research with individuals with physical disabilities: Using theory to advance knowledge. Adapted Physical Activity Quarterly, 10, 324335.

Deci, E .L., and Ryan, R.M. (1985). Intrinsic motivation and self-determination in human behavior. New York: Plenum.

Deci, E.L., and Ryan, R.M. (1991). A motivational approach to self: Integration in personality. In R. Dienstbier (Ed.), Nebraska symposium on motivation: Vol. 38. Perspectives on motivation (pp. 237-288). Lincoln, NE: University of Nebraska Press.

Deci, E.L., Ryan, R.M. (1996)"Need satisfaction and the self regulation of learning", Learning and Individual Differences, 8 (3), pp. 165-183.

Deci, E.L. and Ryan, R.M. (2000). "The "What" And "Why" Of Goal Pursuits: Human Needs And The Self- Determination Of Behavior", Psychological Inquiry, 11, pp. 227-268.

Deci E.L., and Ryan R.M. (2002). Handbookof Self-Determination Research. Rochester, NY: Univ. Rochester Press.

Eichsteadt, C.B. and Lavay, B.W. (1995). Physical Activity for Individuals with Metal Retardation Compaign, Illinois, p.47

Erwin, E. J. and Brown, F. (2000). Variables that contribute to self-determination in early childhood. The Association for Persons with Severe Handicaps Newsletter, 26, 8-10

Ferrara, M.S. and Peterson, C.L. (2000). Injuries to athletes with disabilities. Sports Medicine, Aug, $30,137-143$

Fortier, M. S., Vallerand, R. J., Guay, F. (1995). Academic motivation and school performance: Toward a structural model. Contemporary educational psychology, 20(3), 257-274.

Koparan, S..; (2003) Özel ihtiyacı olan çocuklarda spor. Uludağ Üniversitesi Eğitim Fakültesi dergisi, 1, 17.Bursa.

Moralı, S., Doğan, B., Kazak, Z. and Engür, M. (2004). Sporcuların Güdüsel yönelimlerinin empatik davranım biçimleri açısından değerlendirilmesi, Performans Dergisi, 10(1), p.3.

Seyyar, A. (2013). Bağcılar'da Engelli Politikaları ve Engellilere Yönelik Uygulamalar, (ed.Bozlağan, Recep). Bağcllar Perspektifi; Bağcllar Belediyesi Kültür Yayınları. İstanbul.

Perreault, S. and Vallerand, J. R. (2007). A Test of Self-Determination Theory With Wheelchair Basketball Players With and Without Disability Adapted Physical Activity Quartely. Human Kinetics. (24, 305-316).

Ruddell, J. L. and Shinew, K. J. (2006). The socialization process for women with physical disabilities: The impact of agents and agencies in the introduction to an elite sport. Journal of Leisure Research, 38(3), 421-444.

Ryska, T. A, Hohensee, D, Cooley, D and Jones, C.(2002). Participation Motives in Predicting Sport Dropout. North American Journal of Psychology; 4(1): 57-73

Ryska, T. A. (2003). Sportsmanship in Young Athletes: The Role of Competitiveness. Motivational Orientation and Perceived Purposes of Spot". The Journal of Psychology; 137(3).

Wang, C. K. J. and Biddle S. J. H. (2004) Intrinsic Motivation Towards Sports in Singaporean Students: The Role of Sport Ability Beliefs". Journal of Health Psychology; 8 (2): 67-83 